\title{
THE MEASUREMENT OF EMPLOYMENT STATUS IN SOUTH AFRICA USING COHORT ANALYSIS, 1994-2004
}

\author{
NICOLA BRANSON AND MARTIN WITTENBERG*
}

\begin{abstract}
We analyse trends in employment, unemployment and labour force participation by simple graphical techniques, using all the October Household Surveys and the September Labour Force Surveys. We show that African male employment in 1995 seems high, when compared to all the other surveys. Furthermore much of the increase in African female labour force participation is concentrated in the period 1998 to 2000, which suggests that measurement and sampling changes may be partially responsible for the trend. We track cohorts of individuals over the eleven years for which we have data. We show that young people are leaving school earlier, while being better educated than their elders. They are not, however, being absorbed into employment at a faster rate. This has led to a spike in youth unemployment.
\end{abstract}

JEL Classification: C14, J21, J22

Keywords: employment, unemployment, labour force participation, South Africa, cohort analysis, October Household Survey

\section{INTRODUCTION}

A few years ago South Africa celebrated ten years of democracy. Amidst the fanfare and the celebrations serious questions were being asked about the achievements and challenges facing the country. Labour market issues featured prominently in these discussions. Indeed even the ten year review commissioned by the Presidency (PCAS 2003) noted that job creation was viewed as the most serious public policy issue by the majority of South Africans (p. 94). Measuring the extent of the employment problem and how this has changed in the post-apartheid era has consequently been an important issue for both academic and popular audiences.

South Africa's national household surveys, first the October Household Surveys (from 1994 to 1999) and then the Labour Force Surveys (since 2000) have provided the main source of information for these debates. Most of these analyses, however, have simply taken two or three points in time in order to construct their trends. In this paper we aim to make two simple contributions:

- We present analyses using annual surveys between 1994 and 2004. We are therefore able to pinpoint more accurately where some of the major aggregate shifts seem to be occurring

\footnotetext{
* School of Economics and SALDRU University of Cape Town.

1 This paper is based on Nicola Branson's Honours thesis "The South African Labour Market 1995-2004: A Cohort Analysis", School of Economics, University of Cape Town. We thank Matthew Welch and Lynn Woolfrey of Data First for access to and help with the Statistics South Africa data sets. We thank Murray Leibbrandt, participants at the ERSA Stellenbosch labour workshop and an anonymous referee for helpful comments. We acknowledge support from the Mellon Foundation through their grant to Data First.
} 
- We track labour market changes on successive age cohorts. By following a particular cohort over eleven years, we are able to investigate how its experience of the labour market contrasts with those of older or younger cohorts.

While these analyses are at some level descriptive, they highlight a number of crucial points. Firstly, we show that African male employment in 1995 seems atypical when compared with all the other years. This suggests that 1995 may not be a very good year on which to anchor analyses of post-apartheid employment changes. The performance of the post-apartheid labour market will seem worse than if a different base year had been picked. Nevertheless, as we show below, most comparative analyses do, in fact, base themselves on 1995.

Secondly, we show that the big shifts in female labour force participation that have been noted in the literature seem to be disproportionately concentrated in the period 1998-2000. This suggests that measurement and/or sampling design changes may be at least partially implicated in generating the trend.

Thirdly, we show that the experience of younger cohorts is, in fact, different from those of older ones. Two particular points emerge. Younger cohorts are leaving the education system faster than previous ones, with similar or higher levels of learning. This seems a good thing. Nevertheless they are being absorbed into work at the same rate as previous cohorts. This is undoubtedly disappointing. The net effect is a high level of youth unemployment. We show, however, that while younger cohorts seem to be experiencing more intensive levels of youth unemployment, they also seem to be getting over the "hump" of that problem at a younger age. The major message from this part of the analysis is that unemployment is not a terminal state for the majority. Nevertheless cross-sectional analyses of the prevalence of unemployment are likely to be misleading. We also need the temporal dimension.

The plan of this discussion is as follows. In the next section we will briefly review some of the pertinent literature. In section three we will be introducing the data and the techniques used to analyse them. In section four we will be looking at the series of cross-sections, while in section five we will be turning to the cohort analysis. Section six concludes.

\section{LITERATURE REVIEW}

In Appendix 1 we present a summary of papers that have tried to analyse changes in the post-apartheid labour market using national survey data. There seems to be a consensus in the literature that South Africa has seen some expansion of aggregate employment levels together with a major increase in participation levels. A number of authors have cautioned that measurement changes by Statistics South Africa, particularly improvements in the recording of informal activity, are likely to confound the trends.

In looking over the list of studies assembled in Appendix 1, it is striking how central the 1995 October Household Survey is to many of these analyses. The reasons for this centrality reside in the fact that it is the closest OHS to the advent of democracy which also has a sampling design that seems to be broadly comparable to later years. The 1994 data set would seem even better, but this OHS had fewer clusters and a more strongly racially skewed sample, so many authors seem to have avoided it. Another reason for preferring the 1995 OHS is that it was linked to the Income and Expenditure survey of 
that year, so many poverty analyses gravitated towards that data set. Indeed if we had included poverty studies and analyses of single year cross-sections in our Table, the dominance of 1995 would have been even more impressive.

Our analysis also shows that many (but not all) researchers have shown at least some caution when comparing aggregate data from different surveys. The studies note changes in questionnaire as well as sample design. Despite these reservations, it is clear that one has little option but to use the information available in the national household surveys. We would argue, however, that it is preferable to use more rather than fewer data sets in these analyses, given some of the evident idiosyncracies of the data gathering process.

\section{THE DATA AND METHODS OF ANALYSIS}

In this study we will attempt to address some of the short-comings of the existing literature by using annual surveys since 1994. The starting point for our analysis is a comparison of all of these cross-sections. We will initially be using the approach outlined in Wittenberg (2002). We will examine the proportion of each age cohort that is employed, unemployed on the strict definition, non-searching unemployed, and not economically active (on either the broad or narrow definition of unemployment). We smooth these age - employment status relationships to filter out some of the statistical noise and facilitate comparison between surveys.

This is important because the surveys show some variation in size and design. As noted above, the 1994 OHS was designed significantly differently from later surveys. Since our primary aim is to estimate proportions within particular age cohorts (among Africans) we are not that concerned with these changes, provided that the weights supplied with the data set allow us to correct for the disproportionate sampling. Indeed our exercise can be seen as an initial check on the plausibility of those weights.

The "standard" OHS design consists of a sample of around 30,000 households in 3,000 clusters, whereas the 1994 OHS consisted of 30,000 households in 1,000 clusters. The 1996 and 1998 October household surveys were also run differently to the others. The 1996 survey was much smaller due to the demands placed by the census that was also run in October of that year. It consisted of 16,000 households in 1,600 clusters. These clusters were extracted to be adjacent to the enumerator areas sampled for the postenumeration survey of the 1996 census. Consequently the OHS was also shifted to November. The 1998 survey was also smaller, due to budget constraints. The design called for 20,000 households in 2,000 clusters.

The October Household Surveys were discontinued after 1999 and replaced with the Labour Force Surveys. These surveys were designed to be a rotating panel with $20 \%$ of the sample rotated out after every wave. Waves are run in March and September of each year. The size of each cross-section was intended to be around 30,000 households in 3,000 clusters. Although the rotating panel structure theoretically allows more dynamic analyses in practice it has thus far proved difficult to connect individuals in different waves. Consequently we only use the cross-sectional information. Furthermore we restrict our analyses to the September waves of the LFS.

The next best alternative to panel data is to construct a synthetic panel of age cohorts from the cross-sections. This means tracking groups of individuals through successive surveys. With eleven years of successive data, different cohorts can be observed at the same age. In theory we can use this to differentiate the generational and life-cycle effects (Gruen, 
2004b). In practice we will be using the cohort information mainly descriptively. Branson (2005) provides a decomposition of the observed shifts into "age" and "cohort" effects.

Cohort data has some advantages over panel data. First, panel data suffers progressively from attrition. Attrition occurs when, for some reason, individuals or households are lost from the survey sample. Reasons for attrition include 'loss to follow up', refusal and death. Since the design requires the same individuals to be followed, as time goes on fewer individuals remain in the sample. Since those lost to the survey are not usually lost at random, the sample ends up being unrepresentative of the population. By contrast cohort data is constructed from a new sample each time and is therefore less vulnerable to attrition. The question of how representative the age cohort data are becomes dependent on whether the national cross-sections sample individuals at different ages equally successfully.

A second attractive feature is that the semi aggregate nature of the data forms a connection between the individual and national level data. For instance the national statistics show a rise in unemployment. Through our cohort analysis we can go some way to tracking where this rise comes from - is it mainly from older people who are being retrenched or is it driven by new entrants? As we show below we can literally see successive waves of young entrants washing through the system.

There are two main disadvantages in using cohort data. The aggregation of information leads to a loss of individual information and the underlying assumption of a constant population can be problematic. This assumption is required to ensure that random samples drawn from successive surveys represent a random sample from the same population each year. Aging, migration and death within specific cohorts can distort the population making this assumption unrealistic (Deaton, 1997). In restricting the cohorts to the working years 16-65, it is hoped that aging and death distortions will be avoided. However it is worth noting that the influence of the HIV/AIDS epidemic, with its concentrated attack on people in their productive years, may be problematic for the future use of cohort data.

\section{THE EVIDENCE FROM THE CROSS-SECTIONS}

In Fig. 1 we present our first piece of evidence from the cross-sections. Each line in the diagram represents one cross-section. It tracks the proportion of each age group (among African males) that is employed. The diagram suggests that each cross-section provides a very similar qualitative picture of the labour-force experience. Young African males take a considerable time to become absorbed into employment. Even at the peak (around age 40) only around sixty to seventy percent of African males are employed. The balance is either unemployed or has become not economically active.

While the qualitative picture is consistent across all surveys, the year 1995 looks anomalous. At every age from around twenty-five to fifty-five it seems to show considerably higher levels of employment than the other data sets. The gap between employment in 1995 and the later OHSs is a good ten percentage points at the peak. Of course the years 1994 and 2000 are also higher than the rest, but the gaps are not so extreme.

The higher levels of African male employment in 1995 are of some concern, since African males make up a considerable proportion of the total workforce. Shifts in the employment estimates in this subpopulation are likely to have a considerable influence on the estimates of aggregate employment. 


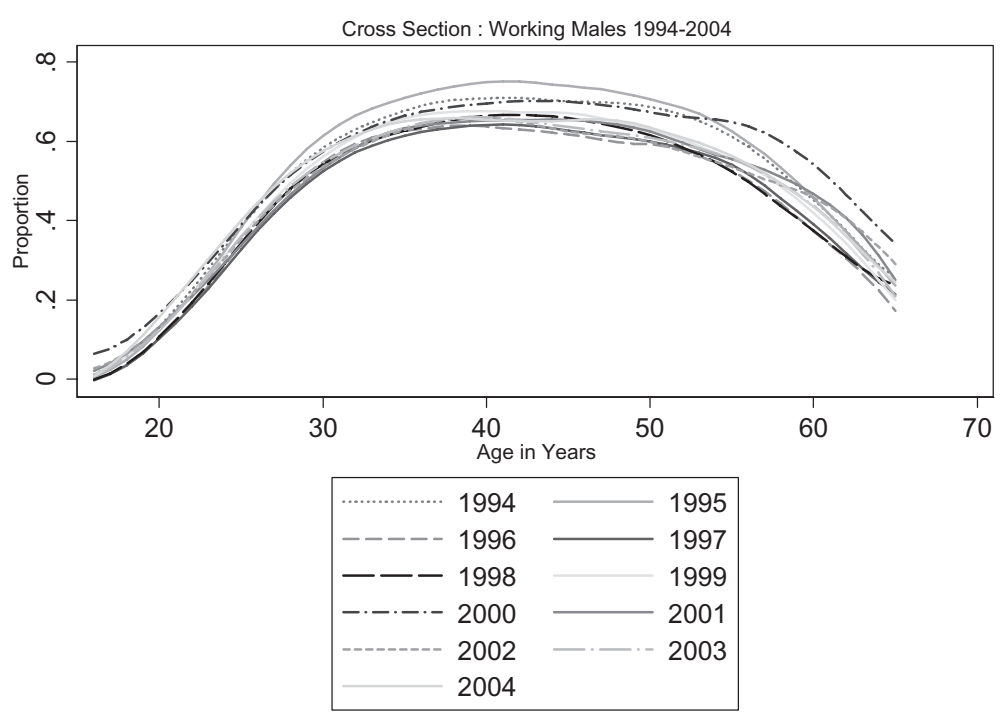

Figure 1. The age-employment profile among African men

The idea that the 1995 OHS may be too successful in picking up employment is not altogether surprising given Wittenberg's (2004) finding that the 1995 OHS found 450,000 more agricultural workers than either the 1996 census or the subsequent two OHSs.

In the corresponding picture for women (shown in Fig. 2) the year 1995 is no longer anomalous, but the year 2000 shows much higher levels of employment than either previous or subsequent surveys. The simplest explanation is that the increased attention to finding informal activities in the LFSs was spectacularly successful in this survey. Arguably the greater year-on-year volatility in the female employment numbers may reflect real or measured changes in informal activity. The higher levels of employment in the 1995 OHS among males cannot be similarly rationalised.

Another set of concerns arise from Fig. 3. We observe that non-participation among women follows the intuitively obvious pattern. At young ages most women are nonparticipants, because they will still be in the education system. The proportion of non-participants drops to its lowest level around age thirty from where it rises again. This rise is driven both by child-raising pressures (at younger ages) and retirement (after sixty).

Looking at all the cross-sections, however, we note that the cross-sections divide neatly into two groups: the October Household Surveys from 1994 to 1998 and the Labour Force Surveys. The former all show much higher levels of non-participation than the latter. The 1999 October Household Survey lies, for indeterminate reasons, almost precisely between these two bands. In short, most of the big increase in participation that has exercised South African labour economists seems to have happened between 1998 and 2000 !

What is somewhat troubling about this picture is that the participation shock seems to have occurred uniformly at all ages. Whatever it was that propelled women into the labour force, it happened among forty and fifty year olds as well as among younger women. The simplest explanation seems to be that at least some of this change in participation is spurious - the result of more diligent efforts on the part of Statistics South 


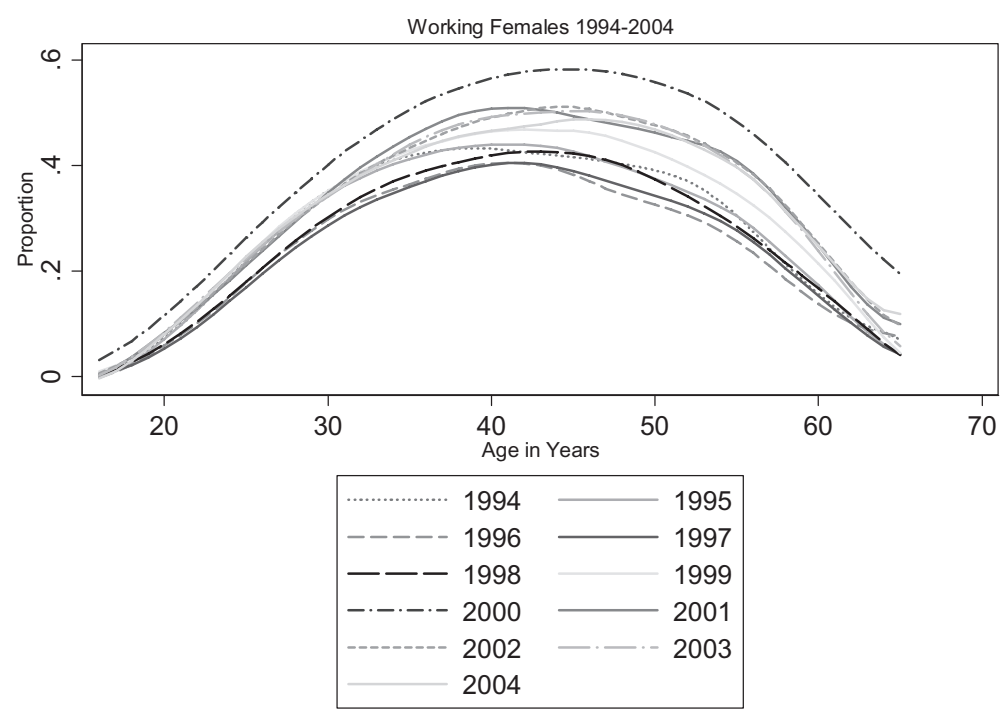

Figure 2. The age-employment profile among African women

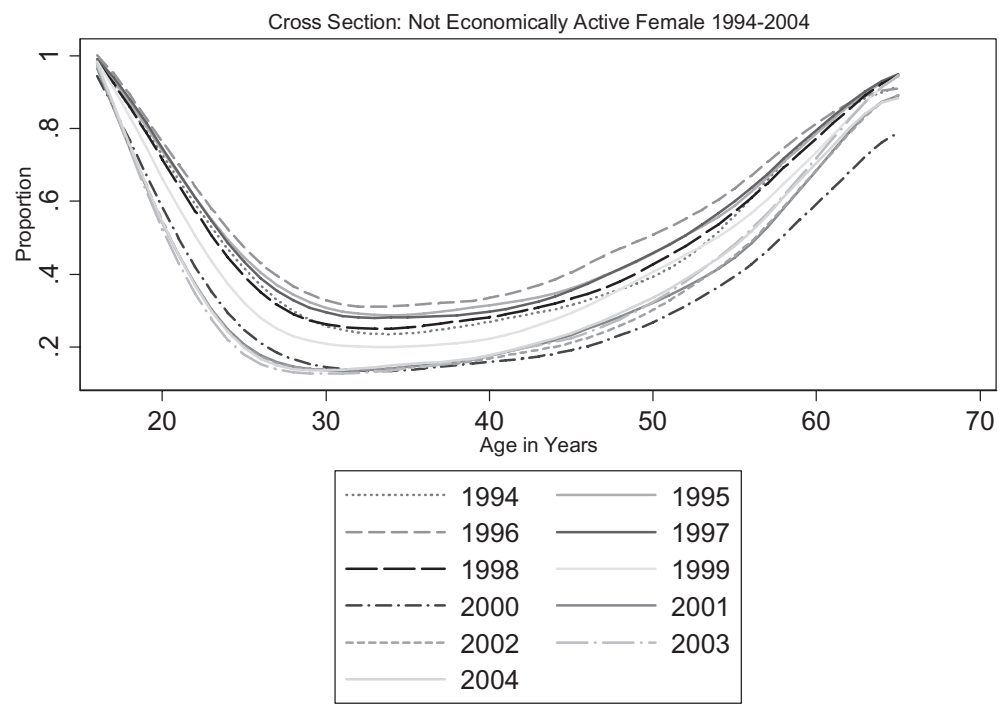

Figure 3. The relationship between age and non-participation among African women

Africa to find informal forms of work. Clearly not all of it is spurious, since there is some evidence of increases in participation between 1996 and 1998 as well as subsequently. How to disentangle the real increases from measurement artefacts is an issue that we leave to subsequent analyses.

The evidence of the cross-sections is therefore mixed. On the one hand many of the cross-sections are providing congruent information. On the other there are some discontinuities and anomalies. These seem to be concentrated around the periods when there were changes in sampling and questionnaire design. 


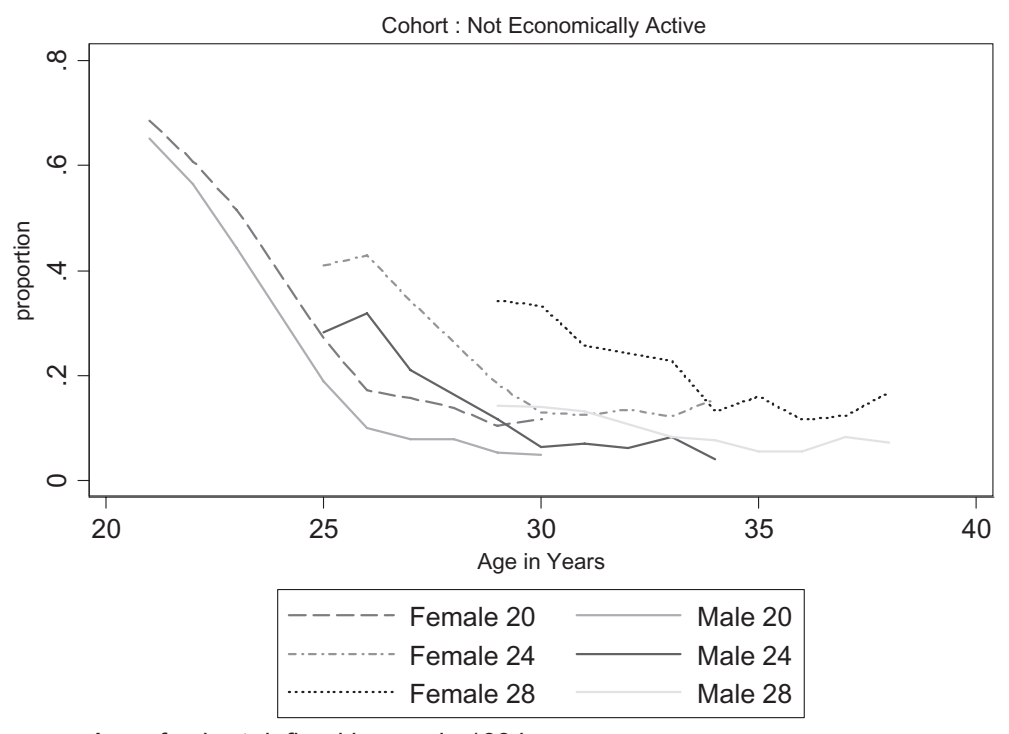

Age of cohort defined by age in 1994

Figure 4. Non-participation among Africans, by selected age cohorts

\section{THE EVIDENCE FROM THE COHORT ANALYSIS}

One problem with relying solely on cross-sectional information is that year-on-year changes in the cross-sectional profile may look somewhat different when looked at from the point of view of an age cohort. Since individuals are aging through these profiles the relevant comparison is not between thirty year olds in 1998 and thirty year olds in 1999, but thirty-one year olds in the later year, thirty-two year olds in 2000 and so on.

In Fig. 4 we show the (inverse) of the process of becoming economically active for three young age cohorts of African men and women. Younger cohorts seem to be leaving the school system much more rapidly than cohorts even a few years older than themselves. All the trajectories reach a similar gender-specific minimum. In the case of women this is around thirteen percent while it is around seven percent for the men. The within-cohort shifts seem much smoother than the cross-sectional adjustments would suggest.

One question raised by Fig. 4 is whether the more rapid transition out of the schooling system is at the cost of lower educational attainment. This does not seem to be the case.

Examining Fig. 5 which displays the highest average education by age in 2004, it is apparent that school drop out rates have not increased. The 'Male 28' cohort depicted in Fig. 4 is aged 39 in 2004 and has attained an education level of around 9 years. The 'Male 20 ' cohort is aged 31 in 2004 and has attained an average of 11 years of education. Thus education levels are not declining, but rather increasing, indicating that young Africans are leaving school with increasing levels of education and on average at a younger age.

They are nevertheless not being absorbed into work at a faster rate. This is shown by Fig. 6. The trajectories of the different age cohorts essentially lie on top of each other, suggesting that younger cohorts of both men and women are becoming employed at precisely the same rate as older cohorts were. One implication of this is that aggregate employment in the economy must be expanding, since these younger cohorts are larger 


\section{Mean Highest Education}

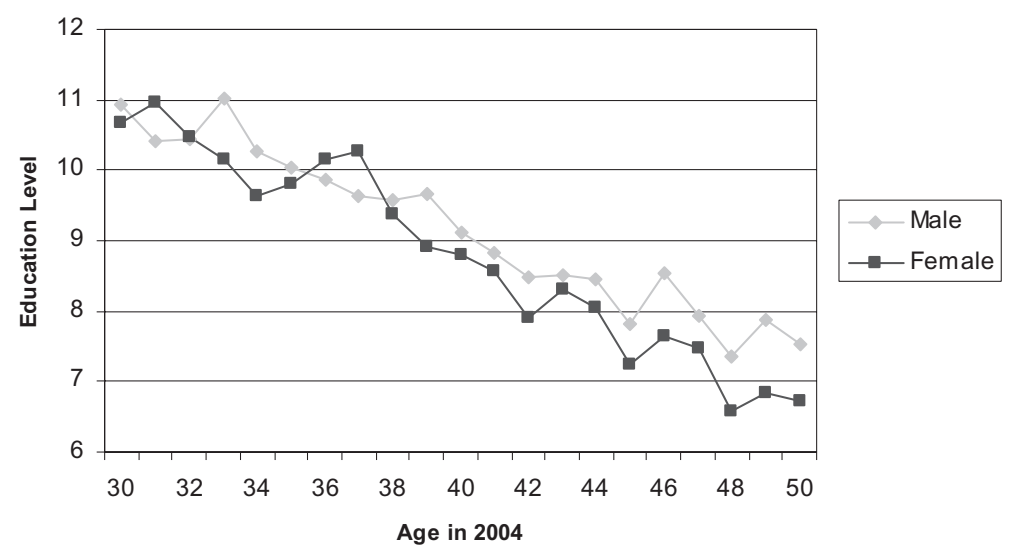

Figure 5. Educational attainment by age cohort

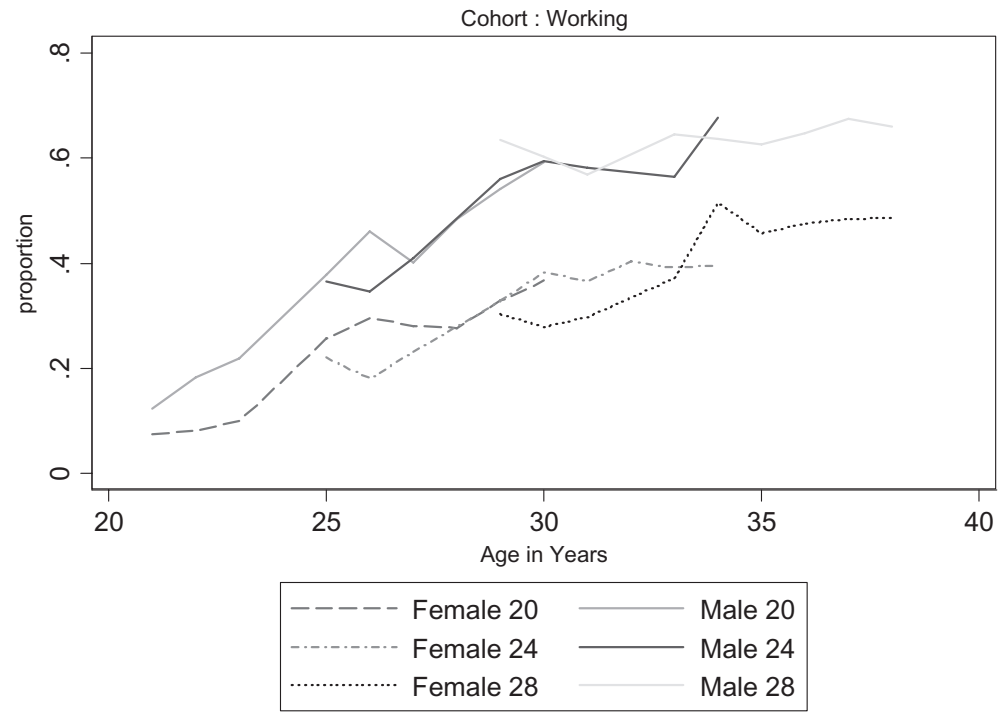

Figure 6. Proportion working, by selected age cohorts

than their predecessors. Nevertheless this increasing availability of jobs is not adequate given the massive supply push shown in Fig. 4. The increased flow of young people into the state of unemployment while faced with a static outflow into employment has inevitably led to an increase in the level of unemployment. This is depicted graphically in Fig. 7.

There are two conclusions that emerge from this figure: the peak level of unemployment has increased substantially; and this peak seems to be occurring at a younger age for younger cohorts. The former conclusion implies that the experience of unemployment is more severe among younger cohorts. Among older cohorts some unemployment would have been disguised by the slower rate of exiting the schooling 


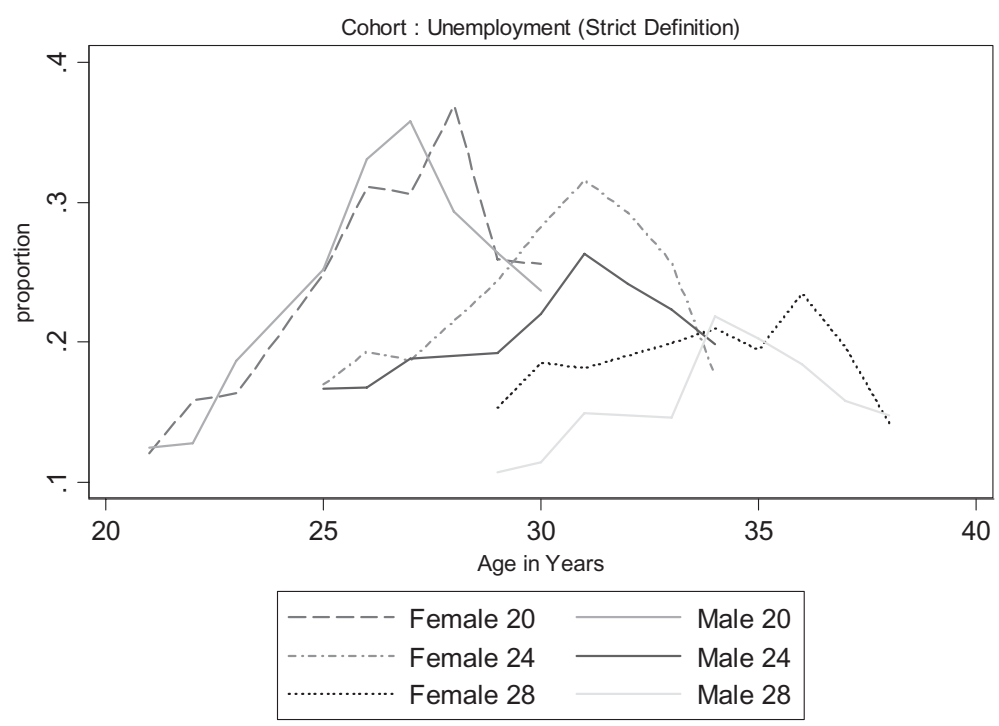

Figure 7. The experience of unemployment, by selected age cohorts

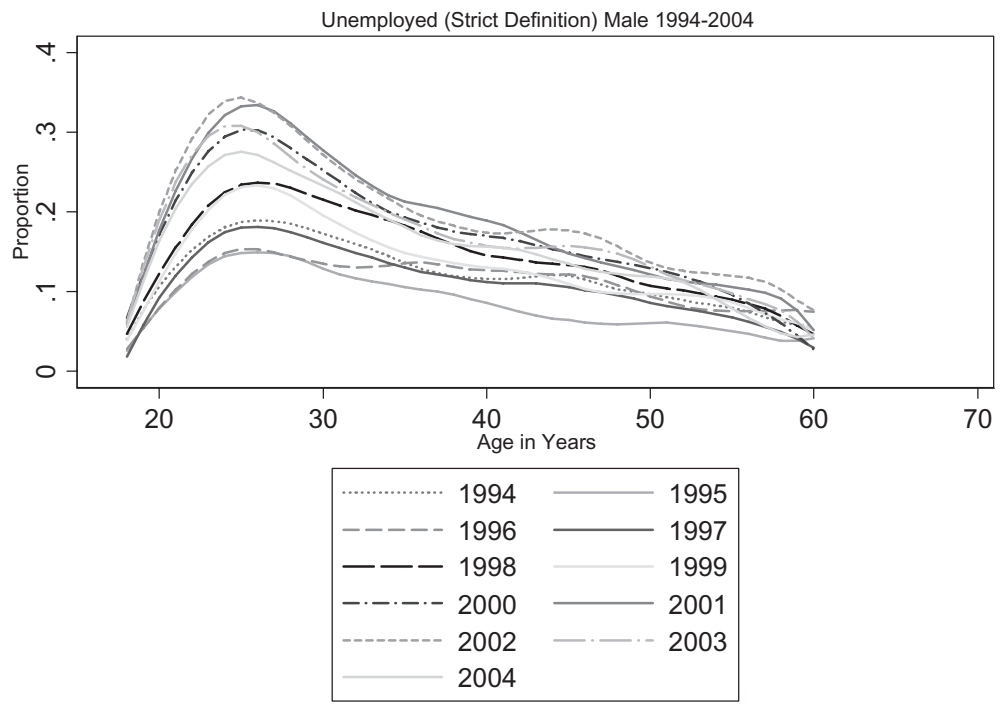

Figure 8. The age-unemployment relationship among African men

system. The latter finding merely confirms that search unemployment is not a terminal condition. Some of the searching unemployed will find jobs; others will become discouraged and drop out completely. That is precisely what search theory would predict (Mortensen and Pissarides, 1999, Pissarides, 2000).

Qualitatively this conclusion is not dissimilar to that reached by Wittenberg (2002) based on single cross-sections. Nevertheless the cross-sectional picture is quite different to that provided by the cohort analysis, as is evident by considering Fig. 8 . The cross-sections all suggest that the turning point in the age-unemployment relationship is reached some 
time in the mid-twenties. As Fig. 7 shows, however, the cohort of 24 year olds in 1994 reached their peak unemployment level only in their early thirties.

\section{CONCLUSION}

The evidence from this paper is mixed. On the one hand we have shown that there are considerable problems in comparing different cross-sectional data sets. There are shifts between these that look to be artefacts of sampling or questionnaire design. On the other hand the cohort analysis provides insights into the underlying processes that seem plausible and consistent with evidence from other surveys of youth unemployment.

The fundamental lesson seems to be that it is unwise to anchor the analysis too heavily on contrasts between two or three data sets. The more information that is brought to bear, the easier it is to spot the statistical blips. In particular we suggest that 1995 is a poor choice for anchoring analyses of changes in post-apartheid employment and unemployment, particularly of African men. We also caution that a non-negligible portion of the "participation" shock among women seems to be driven by measurement changes that occurred between 1998 and 2000.

More substantively, our analysis points to the importance of changes in the rate at which young South Africans are exiting the school system for our understanding of youth unemployment. We have also shown how a cohort perspective can offer a useful corrective to the picture presented by individual cross-sections.

\section{APPENDIX 1 SELECTED PAPERS USING MULTIPLE NATIONAL DATA SETS FOR LABOUR MARKET ANALYSES}

\begin{tabular}{|c|c|c|c|c|}
\hline Paper & Data sets used & Comparability analysed? & $\begin{array}{l}\text { Variables analysed/Type } \\
\text { of analysis }\end{array}$ & Conclusions \\
\hline $\begin{array}{l}\text { Allanson et al. } \\
\quad(2002)\end{array}$ & $\begin{array}{l}\text { OHS } 95,97 \\
\text { Census } 80\end{array}$ & $\begin{array}{l}\text { State that results } \\
\text { are } \\
\text { incompatible } \\
\text { with OHS } 94\end{array}$ & $\begin{array}{l}\text { Oaxaca style } \\
\text { decomposition of } \\
\text { wages (fulltime male } \\
\text { workers) }\end{array}$ & $\begin{array}{l}\text { Between '95 and '97 racial wage } \\
\text { hierarchy widened. Distribution } \\
\text { more compressed in '90s than } \\
\text { in } 1980\end{array}$ \\
\hline Bhorat (2004) & $\begin{array}{l}\text { OHS } 95 \text {, } \\
\text { LFS } 02 \\
\quad(1)\end{array}$ & No & $\begin{array}{l}\text { Numbers employed, } \\
\text { unemployed, } \\
\text { participants } \\
\text { Employed by sector and } \\
\text { skill } \\
\text { Household } \\
\text { characteristics of } \\
\text { unemployed }\end{array}$ & $\begin{array}{l}1.6 \text { million new jobs } \\
\text { Job creation in line with output } \\
\text { growth, but insufficient to } \\
\text { absorb new entrants } \\
\text { New jobs benefit more skilled } \\
\text { Households with unemployed are } \\
\text { poorer }\end{array}$ \\
\hline & OHS 99 & & & \\
\hline \multirow[t]{2}{*}{$\begin{array}{l}\text { Bhorat and } \\
\text { Oosthuizen } \\
\text { (2005) }\end{array}$} & $\begin{array}{l}\text { OHS } 95, \\
\text { LFS } 02(2)\end{array}$ & $\begin{array}{l}\text { Designs } \\
\text { compared }\end{array}$ & $\begin{array}{l}\text { Numbers employed, } \\
\text { unemployed, } \\
\text { participants }\end{array}$ & $\begin{array}{l}\text { Labour force grew faster than } \\
\text { employment, especially among } \\
\text { Africans (especially females); }\end{array}$ \\
\hline & $\begin{array}{l}\text { Mention } \\
\text { LFS 00(2), } \\
01(1), \\
01(2), \\
02(1)\end{array}$ & $\begin{array}{l}\text { Informal sector } \\
\text { information } \\
\text { not so good in } \\
\text { OHS }\end{array}$ & $\begin{array}{l}\text { Formal and informal } \\
\quad \text { employment } \\
\text { Sectoral employment. } \\
\text { Skills } \\
\text { Education } \\
\text { Household characteristics } \\
\quad \text { of unemployed } \\
\text { Unemployment probits }\end{array}$ & $\begin{array}{l}\text { Increased participation among } \\
\text { rural dwellers. } \\
\text { Skilled and semi-skilled are } \\
\text { replacing unskilled workers } \\
\text { Increasing unemployment } \\
\text { among graduates } \\
\text { More unemployed in '02 live in } \\
\text { households with no wage } \\
\text { earners } \\
\text { Formation of poor households } \\
\text { around pensions. }\end{array}$ \\
\hline
\end{tabular}


APPENDIX 1 Continued

\begin{tabular}{|c|c|c|c|c|}
\hline Paper & Data sets used & Comparability analysed? & $\begin{array}{l}\text { Variables analysed/Type } \\
\text { of analysis }\end{array}$ & Conclusions \\
\hline $\begin{array}{l}\text { Branson } \\
\quad(2005)\end{array}$ & $\begin{array}{l}\text { OHS } 95, \\
96,97 \\
98,99 \\
\text { LFS } 00(2) \\
01(2) \\
02(2) \\
03(2) \\
04(2)\end{array}$ & $\begin{array}{l}\text { OHS } 95 \text { seems } \\
\text { to have more } \\
\text { male } \\
\text { employment } \\
\text { than } \\
\text { subsequent } \\
\text { years do }\end{array}$ & $\begin{array}{l}\text { African employed, } \\
\text { unemployed, not } \\
\text { economically active - } \\
\text { by age. }\end{array}$ & $\begin{array}{l}\text { Young Africans seem to be exiting } \\
\text { school system earlier, but with } \\
\text { same level of education. } \\
\text { This supply shift is not } \\
\text { balanced by increases in } \\
\text { employment. } \\
\text { Male age-employment profile is } \\
\text { very stable, i.e. employment is } \\
\text { growing at rate of population } \\
\text { increase, but not faster. }\end{array}$ \\
\hline $\begin{array}{l}\text { Brookes and } \\
\text { Hinks } \\
(2004)\end{array}$ & $\begin{array}{l}\text { OHS } 95,99 \\
\text { LFS 00(2), } \\
01(2) \\
02(2)\end{array}$ & No & $\begin{array}{l}\text { Employment probits } \\
\text { (broad econ active } \\
\text { population) } \\
\text { Oaxaca style } \\
\text { decomposition of these }\end{array}$ & $\begin{array}{l}\text { White-Black gap in probability of } \\
\text { employment has increased over } \\
8 \text { years } \\
\text { (interpreted as an increase in } \\
\text { discrimination) }\end{array}$ \\
\hline Casale (2004) & $\begin{array}{l}\text { OHS } 95, \\
\quad 97,99 \\
\text { LFS 01(2) } \\
\text { Earnings: } \\
\text { OHS } 95 \text {, } \\
\text { LFS 01(2) }\end{array}$ & $\begin{array}{l}\text { Footnote: '97 } \\
\text { employment } \\
\text { data lower } \\
\text { Changes in data } \\
\text { collection of } \\
\text { informal } \\
\text { workers }\end{array}$ & $\begin{array}{l}\text { Numbers employed, } \\
\text { unemployed, } \\
\text { participants } \\
\text { Earnings, Earnings by } \\
\text { education, } \\
\text { Employment type, } \\
\text { Occupation }\end{array}$ & $\begin{array}{l}\text { Increased participation by women } \\
\text { - but little increase in } \\
\text { employment or in access to well } \\
\text { paying jobs } \\
\text { Average real earnings fell } 14 \% \\
\text { Median earnings for women } \\
\text { decreased } \\
\text { Women with degrees had real } \\
\text { earnings growth } \\
\text { Big drop in earnings among } \\
\text { elementary \& service workers }\end{array}$ \\
\hline $\begin{array}{l}\text { Casale and } \\
\text { Posel } \\
\text { (2002) }\end{array}$ & OHS 95, 99 & $\begin{array}{l}\text { Small samples } \\
\text { '96, '98. } \\
\text { Adjust } \\
\text { definitions to } \\
\text { make them } \\
\text { comparable }\end{array}$ & $\begin{array}{l}\text { Numbers employed, } \\
\text { unemployed, } \\
\text { participants }\end{array}$ & $\begin{array}{l}\text { Big increase in female labour force } \\
\text { participation rate: } 38 \% \text { to } 47 \% \\
\text { (narrow), } 48 \% \text { to } 61 \% \text { (broad) } \\
\text { Big increase in unemployment } \\
\text { (particularly broad defn.) } \\
\text { Employment growth mainly in } \\
\text { informal sector } \\
\text { Supply side factors: } \\
\text { Increase in education and decrease } \\
\text { in fertility } \\
\text { Decrease in proportion of women } \\
\text { living with an employed man } \\
\text { Decrease in marriage rate }\end{array}$ \\
\hline \multirow[t]{3}{*}{$\begin{array}{l}\text { Casale et al. } \\
\quad(2004)\end{array}$} & $\begin{array}{l}\text { OHS } 95 \\
97,99 \\
\text { LFS } 00(2) \\
01(2) \\
02(2)\end{array}$ & $\begin{array}{l}\text { Question-naire } \\
\text { design }\end{array}$ & $\begin{array}{l}\text { Numbers employed, } \\
\text { unemployed, } \\
\text { participants. }\end{array}$ & $\begin{array}{l}2 \text { million new jobs between '95 } \\
\text { and '03, but: jump '02 to '03 } \\
\text { (reweight) } \\
\text { Should one exclude subsistence } \\
\text { agriculture? }\end{array}$ \\
\hline & 03(1) & $\begin{array}{l}\text { Prompts for } \\
\text { subsistence } \\
\text { activities }\end{array}$ & Earnings & $\begin{array}{l}\text { Formal sector employment growth } \\
\text { only } 500,000 \text {. } \\
\text { Big increase in labour supply. }\end{array}$ \\
\hline & & Weights & $\begin{array}{l}\text { Estimates of total } \\
\text { earnings by race }\end{array}$ & $\begin{array}{l}\text { Real earnings decreased } 20 \% \\
\text { Decrease in total earnings ' } 95 \text { to } \\
\text { '03. Per capita earnings lower } \\
\text { among Africans (-25\%) and } \\
\text { Whites, higher among } \\
\text { Coloureds and Indians. }\end{array}$ \\
\hline Grün (2004a) & $\begin{array}{r}\text { OHS } 95 \\
97,99\end{array}$ & $\begin{array}{l}\text { Increasing } \\
\text { tendency to } \\
\text { report incomes } \\
\text { in brackets }\end{array}$ & $\begin{array}{l}\text { Selectivity (employ-ment) } \\
\text { corrected Oaxaca type } \\
\text { decomposition of } \\
\text { wages; } \\
\text { Decomposition of } \\
\text { selection effect }\end{array}$ & $\begin{array}{l}\text { Gender discrimination large and } \\
\text { increasing '95-'99. } \\
\text { African women disadvantaged at } \\
\text { hiring stage } \\
\text { White women's selection } \\
\text { probability has increased. }\end{array}$ \\
\hline Grün (2004b) & $\begin{array}{r}\text { OHS } 95 \\
97,99\end{array}$ & No & $\begin{array}{l}\text { Cohort Analysis, Wages } \\
\text { among formal sector } \\
\text { workers }\end{array}$ & $\begin{array}{l}\text { Younger cohorts received wage } \\
\text { gains, except for African } \\
\text { women; Older cohorts had } \\
\text { static or declining wages }\end{array}$ \\
\hline
\end{tabular}


APPENDIX 1 Continued

\begin{tabular}{|c|c|c|c|c|}
\hline Paper & Data sets used & Comparability analysed? & $\begin{array}{l}\text { Variables analysed/Type } \\
\text { of analysis }\end{array}$ & Conclusions \\
\hline $\begin{array}{l}\text { Keswell and } \\
\text { Poswell } \\
\text { (2004) }\end{array}$ & $\begin{array}{l}\text { PSLSD, } \\
\text { OHS } 95,97, \\
\text { LFS } 00(2)\end{array}$ & $\begin{array}{l}\text { Censoring (zero } \\
\text { incomes) } \\
\text { varies across } \\
\text { surveys }\end{array}$ & $\begin{array}{l}\text { Earnings among full-time } \\
\text { workers aged } 15-65 \\
\text { OLS and Tobit Mincerian } \\
\text { wage regressions }\end{array}$ & $\begin{array}{l}\text { Return to primary schooling is } \\
\text { very low; strongly convex } \\
\text { pattern of returns }\end{array}$ \\
\hline $\begin{array}{l}\text { Kingdon and } \\
\text { Knight } \\
(2004 a)\end{array}$ & $\begin{array}{l}\text { PSLSD, } \\
\text { OHS } 94\end{array}$ & No & $\begin{array}{l}\text { Unemployment: } \\
\text { Distribution, Entry } \\
\text { into, Duration. } \\
\text { Probits (against } \\
\text { employed) } \\
\text { Oaxaca style } \\
\text { decomposition of } \\
\text { probabilities }\end{array}$ & $\begin{array}{l}\text { Little prior experience among } \\
\text { African unemployed, Long } \\
\text { durations. } \\
\text { Probability of being } \\
\text { unemployed decreases with } \\
\text { age, education, increases } \\
\text { with home ownership } \\
\text { (Africans), homeland } \\
\text { location. } \\
\text { Gap between African and } \\
\text { white is } 33 \text { pct points. } 8.3 \text { of } \\
\text { these are unexplained. }\end{array}$ \\
\hline $\begin{array}{l}\text { Kingdon and } \\
\text { Knight } \\
(2004 \mathrm{~b})\end{array}$ & $\begin{array}{l}\text { Analyses on } \\
\text { PSLSD } \\
\text { Size of } \\
\text { sector: } \\
\text { OHS } 97,98, \\
99, \\
\text { LFS } 00(1), \\
00(2), \\
01(1) \\
01(2) \\
02(1)\end{array}$ & No & $\begin{array}{l}\text { Size of informal sector } \\
\text { Distribution of } \\
\text { earnings } \\
\text { Predicted earnings of } \\
\text { unemployed in } \\
\text { informal sector. } \\
\text { "Happiness" probits } \\
\text { Intensity of search. } \\
\text { Reservation wages. } \\
\text { Barriers to entry of } \\
\text { informal sector }\end{array}$ & $\begin{array}{l}\text { Unemployed are worse off than } \\
\text { informally employed. } \\
\text { Unemployed are unhappier. } \\
\text { "Reservation wages" seem to } \\
\text { reflect perceived "fair" wage }\end{array}$ \\
\hline $\begin{array}{l}\text { Kingdon and } \\
\text { Knight } \\
(2005)\end{array}$ & $\begin{array}{l}\text { OHS } 95 \\
\text { LFS 03(2) } \\
\text { (mainly) }\end{array}$ & $\begin{array}{l}\text { Note large year- } \\
\text { on-year } \\
\text { fluctuations, } \\
\text { e.g. } 10 \% \\
\text { increase in } \\
\text { employment } \\
\text { '98 to'99. } \\
\text { Definitional } \\
\text { shifts }\end{array}$ & $\begin{array}{l}\text { Numbers employed, } \\
\text { unemployed, } \\
\text { participants. } \\
\text { Formal sector } \\
\text { employed. }\end{array}$ & $\begin{array}{l}\text { Increase in labour force not } \\
\text { matched by increase in } \\
\text { employment. } \\
\text { LF increased more than } 4 \% \text { p.a.! } \\
\text { (but only } 0.8 \% \text { p.a. from } \\
\text { 00(1) to } 03(2) \text { ) } \\
\text { Real wages decreased - more } \\
\text { dramatically in free-entry } \\
\text { sector } \\
\text { Duration of unemployment rose }\end{array}$ \\
\hline $\begin{array}{l}\text { Klasen and } \\
\text { Woolard } \\
\text { (1999) }\end{array}$ & $\begin{array}{l}\text { PSLSD, } \\
\text { OHS } 94, \\
95\end{array}$ & $\begin{array}{l}\text { Compare } \\
\text { definitions, } \\
\text { estimates. } \\
\text { Contrast with } \\
\text { Standardised } \\
\text { Employment } \\
\text { Series }\end{array}$ & $\begin{array}{l}\text { Numbers employed, } \\
\text { unemployed. Labour } \\
\text { force }\end{array}$ & $\begin{array}{l}\text { Household surveys provide a } \\
\text { more coherent picture. } \\
\text { Some care needs to be taken } \\
\text { to correct for some } \\
\text { weaknesses, e.g. } \\
\text { undersampling of } \\
\text { mine workers }\end{array}$ \\
\hline $\begin{array}{l}\text { Klasen and } \\
\text { Woolard } \\
(2000)\end{array}$ & $\begin{array}{l}\text { OHS } 95,96, \\
97 \\
\text { Census } 96\end{array}$ & $\begin{array}{l}\text { Detailed } \\
\text { Comparisons } \\
\text { of definitions } \\
\text { and } \\
\text { measurements } \\
\text { Compare with } \\
\text { STEE }\end{array}$ & $\begin{array}{l}\text { Numbers employed, } \\
\text { unemployed. Labour } \\
\text { force } \\
\text { Employment by sector }\end{array}$ & $\begin{array}{l}\text { Census finds more } \\
\text { participants. } \\
\text { Job shedding '95 to } \\
\text { '97 ( } 300,000) \\
\text { Consistent employment } \\
\text { estimates from } \\
\text { OHS } 95,97 \text { and Census } 96 . \\
\text { Sectoral inconsistencies } \\
\text { (agriculture). } \\
\text { Increasing unemployment } \\
\text { '95 to '97. }\end{array}$ \\
\hline \multirow[t]{2}{*}{ Muller (2003) } & $\begin{array}{l}\text { PSLSD, } \\
\text { OHS } 95, \\
97,99 \\
\text { LFS } 00(2)\end{array}$ & $\begin{array}{l}\text { Compares } \\
\text { definitions, } \\
\text { "hurdle" } \\
\text { questions, }\end{array}$ & Questionnaire design. & $\begin{array}{l}\text { Improvement in questionnaire } \\
\text { design over time. OHS } 97 \\
\text { better than OHS } 95 . \text { LFSs } \\
\text { better still. } \\
\text { Many "formal" sector } \\
\text { workers do not have } \\
\text { formal contracts. }\end{array}$ \\
\hline & $\begin{array}{l}\text { plus } \\
\text { LFS 01(1), } \\
\quad 01(2)\end{array}$ & & Size of informal sector & $\begin{array}{l}170 \% \text { increase in sector } \\
\text { ' } 95 \text { to ' } 01 . \text { Some of this } \\
\text { better measurement. } \\
\text { Decrease in total } \\
\text { employment } \\
\text { '95 to ' } 97 \text {. }\end{array}$ \\
\hline
\end{tabular}




\section{APPENDIX 1 Continued}

\begin{tabular}{|c|c|c|c|c|}
\hline Paper & Data sets used & Comparability analysed? & $\begin{array}{l}\text { Variables analysed/Type } \\
\text { of analysis }\end{array}$ & Conclusions \\
\hline Pirouz (2005) & $\begin{array}{l}\text { OHS } 95,97, \\
99 \\
\text { LFS } 01(2) \\
02(2)\end{array}$ & $\begin{array}{l}\text { LFSs do not have } \\
\text { relationship } \\
\text { codes }\end{array}$ & $\begin{array}{l}\text { Distribution of household } \\
\text { types } \\
\text { Numbers of employed, } \\
\text { unemployed, } \\
\text { participants }\end{array}$ & $\begin{array}{l}\text { Household size has decreased } \\
\text { markedly; Increase in single } \\
\text { person households; } \\
\text { Female headed households increase } \\
\text { from } 28 \% \text { to } 38 \% \text { of } \\
\text { households '95-'02 } \\
\text { "Workless" households increase } \\
\text { from } 13 \% \text { to } 27 \% \text {. } \\
\text { Some "employment } \\
\text { polarisation" } \\
\text { Fewer youth live with parents in } \\
\text { '99 than in '95 }\end{array}$ \\
\hline $\begin{array}{l}\text { Posel and } \\
\text { Casale } \\
(2003)\end{array}$ & $\begin{array}{l}\text { PSLSD, } \\
\text { OHS 95, } \\
97,99\end{array}$ & $\begin{array}{l}\text { Different } \\
\text { household } \\
\text { definitions: } \\
\text { residency } \\
\text { requirement. } \\
\text { Migrant } \\
\text { module in '97 } \\
\text { and '99 }\end{array}$ & $\begin{array}{l}\text { Numbers of migrants. } \\
\text { Destination. } \\
\text { "Migration decision" } \\
\text { probit regression } \\
\text { Remittances }\end{array}$ & $\begin{array}{l}\text { Increase in female migrants } \\
\text { Migration to rural areas ("small } \\
\text { step"). } \\
\text { Role of men in female } \\
\text { migration. } \\
\text { Increase in proportion of } \\
\text { households that receive } \\
\text { remittances }\end{array}$ \\
\hline $\begin{array}{l}\text { Poswell } \\
\quad(2002)\end{array}$ & OHS 95,99 & No & $\begin{array}{l}\text { Numbers employed, } \\
\text { unemployed, } \\
\text { participants. } \\
\text { Sectoral employment } \\
\text { Occupation }\end{array}$ & $\begin{array}{l}\text { Employment increased }(12 \%) \\
\text { Participation increased even } \\
\text { more }(24 \%) \text {. Female } \\
\text { participation increased } 30 \% \text {. } \\
\text { Job shedding in agriculture, } \\
\text { mining, manufacturing, utilities } \\
\text { and government. } \\
\text { More professional jobs. } \\
\text { Poor absorption of graduates - } \\
\text { decrease in Africans with } \\
\text { degrees in public sector? } \\
\text { Real earnings cut ' } 95 \text { to ' } 99 \\
\text { Unionisation rates decreased. }\end{array}$ \\
\hline $\begin{array}{l}\text { Wittenberg } \\
\text { (2002) }\end{array}$ & $\begin{array}{l}\text { PSLSD, } \\
\text { OHS 94, } \\
95\end{array}$ & $\begin{array}{l}\text { Eyeball } \\
\text { comparisons }\end{array}$ & $\begin{array}{l}\text { Proportions of age } \\
\text { cohort that are } \\
\text { employed, } \\
\text { unemployed (strict), } \\
\text { unemployed (broad), } \\
\text { not economically } \\
\text { active. } \\
\text { Nonparametric (lowess) } \\
\text { regression functions of } \\
\text { these relationships. }\end{array}$ & $\begin{array}{l}\text { Spike of youth unemployment. } \\
\text { Difference in "flow rates" out of } \\
\text { education and into } \\
\text { work/dropping out. } \\
\text { Proportion not economically } \\
\text { active also varies with } \\
\text { economic conditions - NEA } \\
\text { should be included in labour } \\
\text { market analysis. }\end{array}$ \\
\hline $\begin{array}{l}\text { Wittenberg } \\
(2004)\end{array}$ & $\begin{array}{c}\text { Census 96, } \\
\text { OHS 95, } \\
96,97\end{array}$ & $\begin{array}{l}\text { Compare } \\
\text { numbers } \\
\text { taking into } \\
\text { account } \\
\text { sampling } \\
\text { variability }\end{array}$ & $\begin{array}{l}\text { Numbers of } \\
\text { manufacturing } \\
\text { workers, sectoral } \\
\text { employment levels, } \\
\text { spatial distribution. } \\
\text { Compared to } \\
\text { Manufacturing Census } \\
1996\end{array}$ & $\begin{array}{l}300,000 \text { missing manufacturing } \\
\text { workers in census } 1996 \text { ? } \\
\text { Confidence intervals for sectoral } \\
\text { and provincial estimates from } \\
\text { the OHSs often do not overlap. }\end{array}$ \\
\hline
\end{tabular}

\section{REFERENCES}

ALlANSON, P., ATKINS, J. P. and HINKS, T. (2002), "No End to the Racial Wage Hierarchy in South Africa?" Review of Development Economics, 6(3):442-459.

BHORAT, H. (2004), "Labour Market Challenges in the post-apartheid South Africa", South African Journal of Economics, 72(5):940-977.

and OOSTHUiZEN, M. (2005), "The Post-Apartheid South African Labour Market", Development Policy Research Unit Working Paper 05/93, University of Cape Town.

BRANSON, N. (2005), "The South African Labour Market 1995-2004: A Cohort Analysis", unpublished Honours Thesis, School of Economics, University of Cape Town.

BROOKES, M. and HINKS, T. (2004), "The Racial Employment Gap in South Africa", South African Journal of Economics, 72(3):573-580

(C) 2007 The Authors.

Journal compilation @ E Economic Society of South Africa 2007. 
CASALE, D. (2004), "What has the Feminisation of the Labour Force 'Bought' Women in South Africa? Trends in Labour Force Participation, Employment and Earnings, 1995-2001”, Development Policy Research Unit Working Paper 04/84, University of Cape Town.

and POSEL, D. (2002), "The Continued Feminisation of the Labour Force in South Africa: An Analysis of Recent Data and Trends", South African Journal of Economics, 70(1):156-184.

- MUlLER, C. and POSEL, D. (2004), "'Two Million Net New Jobs': A Reconsideration of the Rise in Employment in South Africa, 1995-2003”, South African Journal of Economics, 72(5):978-1002.

DEATON, A. (1997), The Analysis of Household Surveys: A Microeconometric Approach to Development Policy, Baltimore: Johns Hopkins University Press.

GRÜN, C. (2004a), "Direct and Indirect Gender Discrimination in the South African labour market", International Journal of Manpower, 25(3/4):321-342.

(2004b), "Racial and Gender Wage Differentials in South Africa: What can Cohort Data Tell?" Paper presented at the African Econometrics Society Conference, University of Cape Town, June 2004.

KESWELL, M. and POSWELL, L. (2004), "Returns to Education in South Africa: A Retrospective Sensitivity Analysis of the Available Evidence", South African Journal of Economics, 72(4):834-860.

KINGDON, G. and KNIGHT, J. (2004a), "Race and the Incidence of Unemployment", Review of Development Economics, 8(2):198-222.

(2004b), "Unemployment in South Africa: The Nature of the Beast", World Development, 32(3):391-408.

(2005), "Unemployment in South Africa, 1995-2003: Causes, Problems and Policies", Global Poverty Research Group Working Paper, GPRG-WPS-010.

KLASEN, S. and WOOLARD, I. (1999), "Levels, Trends and Consistency of Employment and Unemployment Figures in South Africa”, Development Southern Africa, 16: 3-35.

mimeo. (2000), "Unemployment and employment in South Africa, 1995-1997", Report to the Department of Finance,

MORTENSEN, D. T. and PISSARIDES, C. (1999), "New Developments in Models of Search in the Labour Market" in Orley Ashenfelter and David Card, eds., Handbook of Labour Economics. Vol. 3B, Amsterdam: Elsevier, pp. 2567-2627

MULLER, C. (2003), "Measuring South Africa's Informal Sector: An Analysis of National Household Surveys", Development Policy Research Unit Working Paper 03/71, University of Cape Town.

PIROUZ, F. (2005), "Have Labour Market Outcomes Affected Household Structure in South Africa? A Descriptive Analysis of Households", Development Policy Research Unit Working Paper 05/100, University of Cape Town.

PCAS (2003), Towards a Ten Year Review: Synthesis Report on Implementation of Government Programmes, Policy Coordination and Advisory Services (PCAS), Presidency, South Africa. Available at http://www.gcis.gov.za/docs/ publications/10year.pdf

PISSARIDES, C. A. (2000), Equilibrium Unemployment Theory, $2^{\text {nd }}$ edition, Cambridge Mass.: MIT Press.

POSEL, D. and CASALE, D. (2003), "What has been happening to internal labour migration in South Africa, 19931999?" South African Journal of Economics, 71(3):455-479.

POSWELL, L. (2002), “The post-Apartheid South African Labour Market: A Status Report”, Development Policy Research Unit, University of Cape Town.

WITTENBERG, M. (2002), "Job Search in South Africa: A Nonparametric Analysis", South African Journal of Economics, 70(8):1163-1197.

(2004), "The mystery of South Africa's ghost workers in 1996: Measurement and Mismeasurement in the Manufacturing Census, Population Census and October Household Surveys", South African Journal of Economics, 72(5):1003-1022. 